\title{
Array comparative genomic hybridization in confirmation of the deleted genes in a patient with subterminal deletion of the long arm of chromosome 10 associated with sagittal craniosynostosis and dysmorphic features
}

\author{
Ágatha Cristhina Faria ${ }^{1 *}$, Ferraz de Rodrigo Toledo Atique², Maria Regina Galvêas Oliveira Rebouças ${ }^{3}$, \\ Pablo Federico Cavagnaro ${ }^{4}$, Eliete Rabbi-Bortolini ${ }^{5}$, Maria Rita Passos-Bueno ${ }^{2}$, Flávia Imbroisi Valle Errera ${ }^{6}$ \\ From 5th Congress of the Brazilian Biotechnology Society (SBBIOTEC) \\ Florianópolis, Brazil. 10-14 November 2013
}

\section{Background}

Craniosynostosis results from premature ossification of one or more cranial sutures and leads to alterations in the shape of the skull and/or premature closure of cranial fontanels, causing impairment of brain perfusion, vision and hearing, airway obstruction, learning difficulties, severe cosmetic deformities and high intracranial pressure [1]. To date, the genetic mechanisms leading to sagittal craniosynostosis are poorly known. The identification of candidate genes underlying this condition may contribute to elucidation of the etiology of this common malformation. The aim of this study was to associate genotype-phenotype of a patient with a deletion in the long arm of chromosome 10 and craniosynostosis.

\section{Methods}

A newborn female born at term (39 weeks) with birth weight $3.405 \mathrm{~kg}$ and length $45 \mathrm{~cm}$, an occipitofrontal head circumference (OFC) of $36.5 \mathrm{~cm}, 2$ nd pregnancy of a mother at 39 years old and a father at 41 years old, not consanguineous and without family history of congenital anomalies was examined by neonatologists using the Mercks protocol (2003) for early identification of major and minor anomalies. GTG Banding analyzes were performed on metaphase obtained by stimulating peripheral blood lymphocytes from patient and their parents in accordance with standard procedures. The technique

'Universidade Federal do Espírito Santo (UFES), Vitória, Brazil Full list of author information is available at the end of the article
Multiplex ligation-dependent probe amplification (MLPA) was performed using kits for the subtelomeric regions of all chromosomes (P036 and P070-E1-B2 - MRC-Holland). Array Comparative Genome Hybridization (aCGH) (OGT CytoSure ISCA $8 \times 60 \mathrm{k}$ ) was performed according to the manufacturer's recommendations.

\section{Results and conclusions}

The newborn had sagittal craniosynostosis (scaphocephaly), microcephaly, facial asymmetry, short forehead and bitemporal narrowing, microtia, hypoplastic and low-set ears, thin lips, strabismus, retromicrognathia, anteriorized anus, right single palmar crease, short neck, syndactyly of 2-3rd fingers and congenital heart disease. The karyotype was normal and MLPA detected a de novo deletion in region $10 \mathrm{q} 26.2-\mathrm{q} 2$, confirmed by aCGH that showed a $12.9 \mathrm{Mb}$ deletion (122085501-135053489) (The UCSC Human Genome Project Working Draft Build 36/hg 18). Mutations in the FGFR2 gene cause several syndromes that result in craniosynostosis (Crouzon, Pfeiffer, Apert, Jackson-Weiss, Beare-Stevenson Cutis Gyrata) and familial scaphocephaly [2]. The newborn does not have any features suggestive of these syndromes, which may be due to the fact that loss of one allele results in FGFR2 haploinsufficiency instead of gain of function. The PTPRE gene (receptor tyrosine phosphatase type E) is involved in the formation and differentiation of osteoblasts and its allelic absence may explain the craniosynostosis phenotype [2]. In addition, hemizigosis for ATE1 gene may explain heart 
disease, as it encodes an arginyltransferase, enzyme responsible for posttranslational arginylation, a crucial molecular mechanism for the development of heart failure. Our results are corcordant with studies in mice reporting that depletion of arginyltransferase promotes congestive heart failure [3]. Other phenotypic signs found in this newborn may be related to the absence of BNIP3, MKI67, DOCK1, ADAM8 and ADAM12 genes, most of which are responsible for cell signaling, proliferation and differentiation. Reports of craniosynostosis patients with de novo deletions are important to characterize the patients phenotypes, and associate them with specific genes, which will contribute to the improvement of genetic counseling for this condition $[4,5]$

\section{Acknowledgements}

We thank the Institute of Biosciences of USP for technical support and PPSUS - SESA/FAPES/CNPq for financial support.

\section{Authors' details}

${ }^{1}$ Universidade Federal do Espírito Santo (UFES), Vitória, Brazil. ${ }^{2}$ Instituto de Biociências, USP, São Paulo, SP, Brazil. ${ }^{3}$ Hospital Infantil Nossa Senhora da Glória (HINSG), Vitória, ES, Brazil. ${ }^{4}$ Facultad de Ciencias Agrarias - Universidad Nacional de Cuyo/ INTA-EEA La Consulta, Mendoza, Argentina. ${ }^{5}$ Associação Educacional de Vitória (AEV/FAESA), Vitória, ES, Brazil. ${ }^{6}$ Centro de Pesquisa, EMESCAM, Vitória, ES, Brazil.

Published: 1 October 2014

\section{References}

1. Cohen MM: Perspectives on craniosynostosis. West J Med 1980, 132:507-513.

2. Passos-Bueno MR, Sertié AL, Jehee FS, Fanganiello R, Yeh E: Genetics of Craniosynostosis:Genes, Syndromes, Mutations and Genotype-Phenotype Correlations Craniofacial Sutures. Development, Diseases and Treatment. In Front Oral Biol. Volume 12. Basel: Karger;Sharp P. 2007:107-143.

3. Ribeiro PA, Ribeiro JP, Minozzo FC, Pavlov I, Leu NA, Kurosaka S, Kashina A, Rassier DE: Contractility of myofibrils from the heart and diaphragm muscles measured with atomic force cantilevers: effects of heart-specific deletion of arginyl-tRNA-protein transferase. Int J Cardiol 2013, 168(4):3564-3571.

4. Courtens W, Wuyts W, Rooms L, Pera SB, Wauters J: A Subterminal Deletion of the Long Arm of Chromosome 10:A Clinical Report and Review. American Journal of Medical Genetics 2006, 140(4):402-409.

5. Yatsenko SA, Kruer MC, Bader PI, Corzo D, Schuette J, Keegan CE, Nowakowska B, Peacock S, Cai WW, Peiffer DA, Gunderson KL, Ou Z, Chinault AC, Cheung SW: Identification of critical regions for clinical features of distal 10q deletion syndrome. Clin Genet 2009, 76(1):54-62.

doi:10.1186/1753-6561-8-S4-P1

Cite this article as: Faria et al:: Array comparative genomic hybridization in confirmation of the deleted genes in a patient with subterminal deletion of the long arm of chromosome 10 associated with sagittal craniosynostosis and dysmorphic features. BMC Proceedings 2014 8(Suppl 4): P1.

\section{Submit your next manuscript to BioMed Central and take full advantage of:}

- Convenient online submission

- Thorough peer review

- No space constraints or color figure charges

- Immediate publication on acceptance

- Inclusion in PubMed, CAS, Scopus and Google Scholar

- Research which is freely available for redistribution

Submit your manuscript at www.biomedcentral.com/submit
C BioMed Central 